\title{
EU States and the Refugee Crisis in the Former the Yugoslavia
}

\author{
Michael Barutciski
}

\section{Burden-Shifting Arrangements}

The response of European Union (EU) staltes regarding refugees from the forther Yugoslavia should be considered in light of recent developments that have led to burden-shifting arrangements. These arrangements have followed the large increase of refugee claims in western Europe during the 1980 s which resulted in overburdened national refugee determination procedures.

EU states have been particularly interested in improving the control of refugee flows before the evolving union eliminates internal barriers to freedom of movement. ${ }^{1}$ Since these states recognize that the ending of internal border controls greatly limits their national competence over immigration, they have been seeking agreement on common criteria to regulate the entry of foreigners.

The main concern is to prevent freedom of movement from increasing illegal activities such as drug trafficking, organized crime and terrorism. Irregular migrations have also been associated to these types of criminal activities as a common policy of deterrence is being developed. EU states are worried that refugee claimants might enter by the state with the most relaxed external border controls and then take advantage of the suppression of internal border controls in order to seek out and settle in the state with the most enviable living conditions. The fear is that this would in turn encourage illegal migration and result in an increase in abusive claims.

In order to avoid this situation, a coordinated approach is being developed. Negotiations have already led to the signing of several intergovernmental agreements ${ }^{2}$ : the Schengen

\footnotetext{
Michael Barutciski is a Atle Grahl-Madsen Fellow in Law at CRS, York University.
}

Agreement ${ }^{3}$ and Schengen $\mathrm{II}^{4}$ on the elimination of internalborder controls, and the Dublin Convention ${ }^{5}$ which establishes the state responsible for examining an asylum claim.

The first aspect of this coordinated approach is the duty to systematically impose visa requirements on the nationals of most migrant-generating countries. This policy is enforced by sanctioning carriers which transport asylum seekers and others not in possession of the requisite visa. The second aspect of the approach is to deny to those refugees that manage to get around the access barrier the ability to choose a state of protection. It is generally only the state which issued the visa or in which the refugee claimant first arrived that will have to examine and deal with the claim. The effect strengthens the mechanisms of external deterrence because any member state which does not fend off the inflow of refugees finds itself imposed with particular duties. ${ }^{6}$

Several other states have indicated their willingness to be associated with this process. Consequently, a Dublin Parallel Accord has been drafted and adopted in June 1992 which allows non-EU states to join in a mechanism that is similar to the one found in the Dublin Convention. The EU's objectives regarding asylum seekers are becoming increasingly clear as states such as Poland have signed on. ${ }^{7}$ If these new signatory states do not want to be considered as potential states of first asylum and thereby receive refugee claimants returned from western European states, they must either block their borders to potential refugee claimants or seek similar arrangements with adjacent states (preferably both). The intention is to force these "buffer" states to control their borders more effectively and prevent the entry of asylum seekers who would like to make refugee claims in western European states.
It is important to note that nowhere in any of these instruments is there any mention of procedural or substantive harmonization of affirmative norms of refugee law. No account is taken of the critical variations in recognition rates for persons with comparable claims. ${ }^{8}$ Instead, it is assumed that the treatment refugee claimants obtain in one participating state discharges the other states from their duties. The overall result of this coordinated approach greatly reduces the options available to refugees. ${ }^{9}$

\section{Escape From Armed Conflict}

When the crisis in the former Yugoslavia began, the western European states were about to start negotiations leading up to the Maastricht summit in December, 1991. Although they were not prepared for this new problem, they immediately involved themselves by sending diplomatic missions to the area.

When people from Croatia started crossing international borders in order to seek refuge, some countries adopted special measures to allow the admission of these refugees. Hungary, Austria and Italy were naturally the first countries to face refugee flows and they responded by accepting several thousands of refugees. They were later followed by Sweden, Switzerland, and Germany which admitted tens of thousands of people fleeing the war zone. These countries either dropped the visa requirements for ex-Yugoslav nationals or provided a form of provisional admission. ${ }^{10}$

However, other EU members did not admit very significant numbers of refugees. Furthermore, when the war started to spread in early 1992, many countries such as Germany tried to limit the numbers arriving on their territory by stiffening their entry policies. This was followed by the adoption of restrictive measures by countries that were geographically 
even closer to the war zone such as Austria and Hungary. Eventually, even the former Yugoslav republics of Slovenia and Croatia tried to limit the number of people fleeing from BosniaHerzegovina

Yet as the horrors of what was going on in Bosnia-Herzegovina started appearing on television sets, most European countries relaxed their entry policies. This attitude was reversed once again in the beginning of 1993, as EU ministers agreed to stiffen visa requirements and diminish the possibility of massive arrivals of refugees. This game of dropping or imposing visa requirements continues. It has proven to be a somewhat effective way for politicians to accept or refuse refugees depending on the public mood. ${ }^{11}$

It should be noted that even though European states have not opened their borders to refugees from the former Yugoslavia, they have not completely closed them either. As shown in Table 1 , more than 500,000 refugees have sought asylum in the member states.

Table 1: Number of Refugees from the Former Yugoslavia in various European States as of Dec. 31, 1993.

$\begin{array}{lr}\text { State } & \text { No. of Refugees } \\ \text { Germany } & 300,000 \\ \text { Sweden } & 50,000 \\ \text { Austria } & 74,300 \\ \text { Italy } & 32,000 \\ \text { Turkey } & 20,000 \\ \text { Switzerland } & 14,500 \\ \text { France } & 7,000 \\ \text { United Kingdom } & 6,600 \\ \text { Total } & \mathbf{5 0 4 , 4 0 0} \\ \text { Source: World Refugee Survey 1994.p.41. Washing- } \\ \text { ton: US Committee for Refugees. }\end{array}$

However, this hesitancy and ambiguous message has had serious consequences for refugees from BosniaHerzegovina. Croatia, the most important state of first asylum for refugees from Bosnia-Herzegovina, decided in July, 1992 that it could no longer count on other European countries to provide assistance for the refugees it was receiving. Since the government of Croatia considered that it had reached the maximum number of refugees for which it could provide asylum, it closed the border and stopped admitting refugees from Bosnia-Herzegovina.

The desire to contain the refugee flow was openly discussed on 29 July 1992 at the International Meeting on Humanitarian Aid to the Victims of the Conflict in the Former Yugoslavia. Western European states reacted positively to the Slovenian proposal of creating "safe havens" in BosniaHerzegovina. By having certain regions that are safe so that people would not have to leave in the first place, the pressure on asylum countries would thus be relieved.

\section{Right To Remain}

It is generally in this context that a new 'right to remain' has been mentioned. By protecting the right of people to remain in safety in their homes, it is hoped that refugee flows will be prevented. The idea is that refugee protection will be enhanced if emphasis is placed on the basic right of the individual not to be forced into exile.

The promotion of this new right should not come as a surprise. With the situation in the former Yugoslavia, UNHCR has seen its humanitarian role increase significantly. Concurrently, western governments have increased their financial contributions to UNHCR which in turn has naturally led the organization to deal with people who have been displaced in a manner that is conceptually compatible with the desires of these governments.

Likewise, we have seen UNHCR increasingly talk about preventive protection over the last few years. The goal is to eliminate the causes of displacement and give potential displaced persons and refugees the option of remaining in their homes:

Preventive protection is activity undertaken to attenuate the causes of displacement, so that choosing to remain home is a humane and viable option... Though UNHCR intends to develop the concept of preventive protection, it does not intend to do so at the expense of the principles of non-refoulement and asylum (emphasis added).$^{12}$
Despite these assurances, the development of preventive protection at the expense of asylum does accurately describe the general tendency in the international refugee protection regime. UNHCR has in fact changed from an organization that had a strictly palliative role to one that is focusing on fixing the problems that cause refugee flows. This evolution has become even clearer in the former Yugoslavia as external asylum protection has largely been replaced by internal assistance. Indeed, it was not long before powerful European governments made the transition from giving refugees the possibility of "choosing to remain" to becoming the champions of the refugees' new right to remain. In an example of the manipulation of human rights rhetoric, Western governments openly expressed their views that ethnic cleansing would be supported if refugees were resettled abroad. Referring to this position, Frelick writes:

By analogy, it would be like refusing refuge to the victims of the Nazi Holocaust by saying that one did not want to contribute to Hitler's 'ethnic cleansing' of the Jews, all the while barring their escape so that rather than lose their homes and countries, they would lose their lives. ${ }^{13}$

This development has to be examined since its consequences on people attempting to find refuge are very serious. The promotion of this new right to remain presupposes that international law does not at present deal satisfactorily with displacement. It will be noted that there is effectively no general and explicit prohibition of displacement in international law. However, if the international protection system does not deal with displacement in a clear and comprehensive way, this is because the refugee regime purposefully and strategically did not seek to focus on the prohibition of displacement. International refugee law has been conceived as having a distinctive palliative orientation which complements and helps the implementation of human rights law. By reserving a sphere of autonomy for victims of human rights violations, international 
refugee law allows and empowers them to leave the abusive situation. The idea is that the international community contributes by providing relief in the form of temporary asylum. Conceived in these terms, the role of international refugee law is to provide a source of interim protection until the risks in the state of origin no longer exist. This approach does not directly attack oisplacement and the human rights poblem surrounding it, since its concerit is rather to give victims a certain amount of autonomy by having some control over their fates and allowing them to seek asylum.

The approach suggested by the states that are promoting the right to remain constitutes a fundamentally different vision of the role of international refugee law. The focus is no longer on securing a refuge outside the state of origin but rather on attacking the problem at what is believed to be its source. In this sense, the existence of a right to remain essentially undermines the right of seeking asylum and freedom of movement by having international refugee law collapse into international human rights law. This evidently poses a problem if one believes that refugee law should remain conceptually distinct from general human law. Indeed, it should be remembered that refugee law is concerned about the protection of a particular group of people who have already been victims of human rights violations.

Most importantly, the right to remain by itself will not decrease the possibility of displacement. What will affect the likelihood of a coerced population movement is the relative safety of a region. Whether the right to remain can actually help in making a region safer or whether it will end up as one more unenforceable right depends on the international commitment. There are however many risks. As the case in the former Yugoslavia has shown, it is tempting for states to give the impression that they are in favour of such policies of humanitarian intervention. Yet when the time comes for real action, consensus is found only for limited types of intervention which prove to be insufficient to actually stop displacement. Instead, these interventions mainly serve to maintain a facade of humane concern. In the meantime, receiving states can adopt the necessary measures so that displaced persons have no choice but to remain in their state.

Indeed, the current practice of many states raises concerns regarding the future of the right to seek asylum. In the context of burden-shifting arrangements, there is a real risk that receiving states will view migration away from human rights violations as inappropriate and that this vision will be encouraged by the existence of a right to remain. In effect, the right to remain gives states that want to contain refugee flows a new argument that is phrased in human rights terms and can thus be used to cloak restrictive measures. Various forms of humanitarian intervention can therefore become attractive methods that self-interested states use to avoid international obligations.

The resulting negative use of the right to remain could develop into a veritable affront to the autonomous right to access an interim remedy when residence in the state of origin ceases to be viable. Far from a right which can be exercised freely, the right to remain would then contribute in eliminating all options. ${ }^{14}$

\section{Growing Number of de facto Refugees}

The treatment of refugees from the former Yugoslavia who have managed to access EU territory also illustrates the inadequacies of the current international legal refugee definition that is used by most European states. By defining refugees exclusively in terms of persons who fear persecution based on their political or civil status, the 1951 Convention is not very useful in protecting war refugees.

Even if most EU states have very small refugee status acceptance rates (generally between 5-15 percent), in practice they have been unwilling to deport war refugees. ${ }^{15}$ These refugees who do not qualify for Convention status are therefore given permission to stay under a designated "B status," "de facto status," "humanitarian status," etc. While this is more desirable than deportation, it often leaves these involuntary migrants in a sort of legal limbo with minimal or no rights.

The significance of this development is that there is now in Europe a new uncertain category of legal migrant that is not accorded full rights. Without a real legal framework to protect these involuntary migrants, their status remains ad hoc and subject to the whims of domestic politics. In the context of European populations that are increasingly becoming xenophobic, this is not a desirable form of international protection for refugees.

\section{Emerging Norm of Temporary Protection}

Thus, the refugees from the former Yugoslavia that have been admitted in EU states have generally not been legally recognized as Convention refugees. According to EU collective policy decisions, people fleeing the former Yugoslavia are to be accorded a form of temporary protection. In effect, these refugees obtain an authorization for a temporary stay which varies from state to state. In some states, refugee claims are still accepted even though the decisions are not given full effect. In other states, the whole treatment takes place outside the regular refugee status determination procedure. One advantage for EU states is that the lengthy and costly determination procedures are avoided. In cases of massive arrivals, this is even more important since decisions regarding refugee status cannot be made in a reasonable time limit.

UNHCR has announced that certain minimal conditions must be observed during the period when temporary protection is provided: admission at the border, respect of fundamental needs and authorization to stay until safe return is possible. If these conditions are respected, then UNHCR believes it is not necessary to allow beneficiaries of temporary protection to 
have access to determination procedures. UNHCR has in effect accepted temporary protection as part of its mandate while justifying it as a pragmatic solution to a complicated problem. ${ }^{16}$

There is a serious problem in that it seems EU states are actually quietly subtracting themselves from international obligations concerning refugees. This is why UNHCR has insisted that the "freeze" on the examination of refugee status claims must only be temporary. The beneficiaries of temporary protection would therefore have access to the refugee status determination procedure if they are no longer accorded temporary protection. In practice, however, once temporary protection nolonger applies, then refugee status acceptance rates will likely be very small. In the meantime, a mechanism that allows EU states to avoid international obligations while preserving a different form of humanitarian protection will have been implemented.

It should be recognized that this EU policy on temporary protection is not incompatible with the general objectives of the burden-shifting arrangements and the promotion of a right to remain-objectives that has preoccupied powerful states in the Union. The general restrictive policies meant to prevent the arrival of refugees can continue (and serve a complementary role) since temporary protection only commits EU states if refugees somehow do manage to arrive on their territories.

The result is clear. In a context where states are giving up part of their sovereignty in order to participate in the increasing globalization of economic activities, the right to exclude aliens is jealously guarded. If this is the EU response to a refugee crisis in its own back yard, we can only imagine what the response will be to situations on other continents. Unless there is a reform of the international protection regime which attempts to take full advantage of what states are in fact prepared to do, the future for the protection of refugees promises to be bleak.k
The example of former Yugoslavia shows that EU states are willing to provide a form of temporary protection for a limited number of refugees. However, the bulk of the assistance takes place in the region of origin. Any realistic attempt at changing the direction of recent developments in refugee protection must fully exploit these openings. Otherwise, states will deal with the problem by themselves and the emerging regime will most likely provide even less protection for refugees.

\section{Notes}

1. The 1957 Treaty Establishing the European Economic Community has been modified by Article 8A of the 1986 Single European Act in order to establish "an area without internal frontiers in which the free movement of goods, persons, services and capital is ensured." Article 8 of the Maastricht Treaty on European Unity further establishes the concept of European Union citizenship which grants to all citizens of the Union the right to move and reside freely within the territory of any member state.

2. "The advantages of an intergovernmental approach for states committed to deterrence are clear. Because critical decisions have been taken within an international body and codified in international agreements, governments have not had to contend with the vagaries of a domestic policy debate. Yet by avoiding the supranational fora of the Council of Europe and European Community, it has proved possible to achieve the coordination of immigration policy without any formal renunciation of domesticjurisdiction or submission to substantive scrutiny and procedural accountability. There has thus been no imperative to engage in the balancing of communal closure and the human rights of coerced migrants that an open and principled reform of refugee law would have required." J. Hathaway, "Harmonizing for Whom? The Devaluation of Refugee Protection in the Era of European Integration," (1993) 26 Comell International Law Joumal 719, at 733.

3. Schengen Agreement of 14 June 1985 relating to the Gradual Suppression of Controls at Common Frontiers, between the Government of States Members of the Benelux Economic Union, the Federal Republic of Germany and the French Republic ("Schengen Agreement").

4. Convention on the Application of the Schengen Agreement of 14 June 1985 relating to the Gradual Suppression of Controls at Common Frontiers, between the Government of States Members of the Benelux Economic Union, the Federal Republic of Germany and the French Republic ("Schengen II").

5. Convention Determining the State Responsible for Examining Applications for Asylum Lodged in One of the Member States of the European Economic Communities ("Dublin Convention").

6. "UNHCR is concerned where the emphasis on this 'authorization principle' has the effect of causing States to strengthen even further both their entry requirements (visa arrangements) and their mechanisms to enforce these requirements (airline sanctions)." UNHCR, UNHCR Position on Conventions Recently Concluded in Europe (Dublin and Schengen Conventions), August 1991, p. 4.

7. See UNHCR, Overview of Re-admission Agreements in Central Europe, 30 September 1993.

8. See Amnesty International, Europe: Human Rights and the Need for a Fair Asylum Policy, 1991.

9. "While it is important that governments are able to remove clearly fraudulent asylum applications from the process as swiftly as possible, an asylum policy based solely on an accelerating process of control and deterrence throughout the Community weakens refugee protection." G. Loescher, "The European Community and Refugees," (1989) 65 International Affairs 617, at 631 .

10. See T. Argent, Croatia's Crucible: Providing Asylum for Refugees from Bosnia-Herzegovina, Washington: US Committee for Refugees, October 1992, p. 17.

11. For indications of which countries imposed or removed visa requirements during the summer of 1993, see, for example, Amnesty International, Bosnian Refugees: A continuing need for protection in European countries, London, July 1993, p. 2.

12. D. Stafford, "New Strategies for Refugees in the 1990s," (1992) 91 Refugees 10, at 13.

13. B. Frelick, "Preventing Refugee Flows: Protection or Peril?" in US Committee for Refugees, World Refugee Survey 1993, Washington: 1993 , p. 9-11.

14. We should consider Frelick's warning concerning the international community's response to the situation of Kurds from northern Iraq in 1991: "This was not an effort to address the root causes of the refugee flow so that potential refugees would feel secure enough to choose not to leave. In fact, they had no choice. Asylum in neighbouring Turkey was denied, and the assistance that did arrive came as much to shore up political alliances with friendly governments and to challenge the enemy regime as it did to assist the refugees." B. Frelick, id, p. 9.

15. There are some estimates that 80 percent of all rejected refugee claimants actually remain in the country where they presented a claim or in another western European country. See European Consultation on Refugees and Exiles, Working Paper on the Need for a Supplementary Refugee Definition, April 1993, p. 2.

16. The nature of the problem is partly reflected in the following explanation: "Cette approche globale trouve sa signification dès lors qu' on la rapporte au contexte politique de fermeture des frontières que connaissent les pays industrialisés. Promouvoir une protection temporaire était pour le HCR le seul moyen de rassurer les États en réduisant 'leur degré d'obligations' et tout en limitant les refus d'accueil de personnes en quête d'asile." V. Cochetel, "Position du HCR par rapport a la protection temporaire et au statut humanitaire" in France Terre d'Asile, Le droit d'asile au regard de la crise yougoslave - protection temporaire et statut de réfugic, Septembre 1993, p. $8 . \square$ 


\section{Refuge \\ York Lanes Press \\ Centre for Refugee Studies \\ Suite 351, York Lanes, York University \\ 4700 Keele Street, North York \\ Ontario, Canada M3J 1P3 \\ Phone: (416) 736-5843 - Fax: (416) 736-5837 \\ Electronic Mail via Bitnet Address: refuge@vm1.yorku.ca \\ Postage Paid in Toronto, Canada \\ Second Class Mail Registration No. 5512 \\ Return Postage Guaranteed}

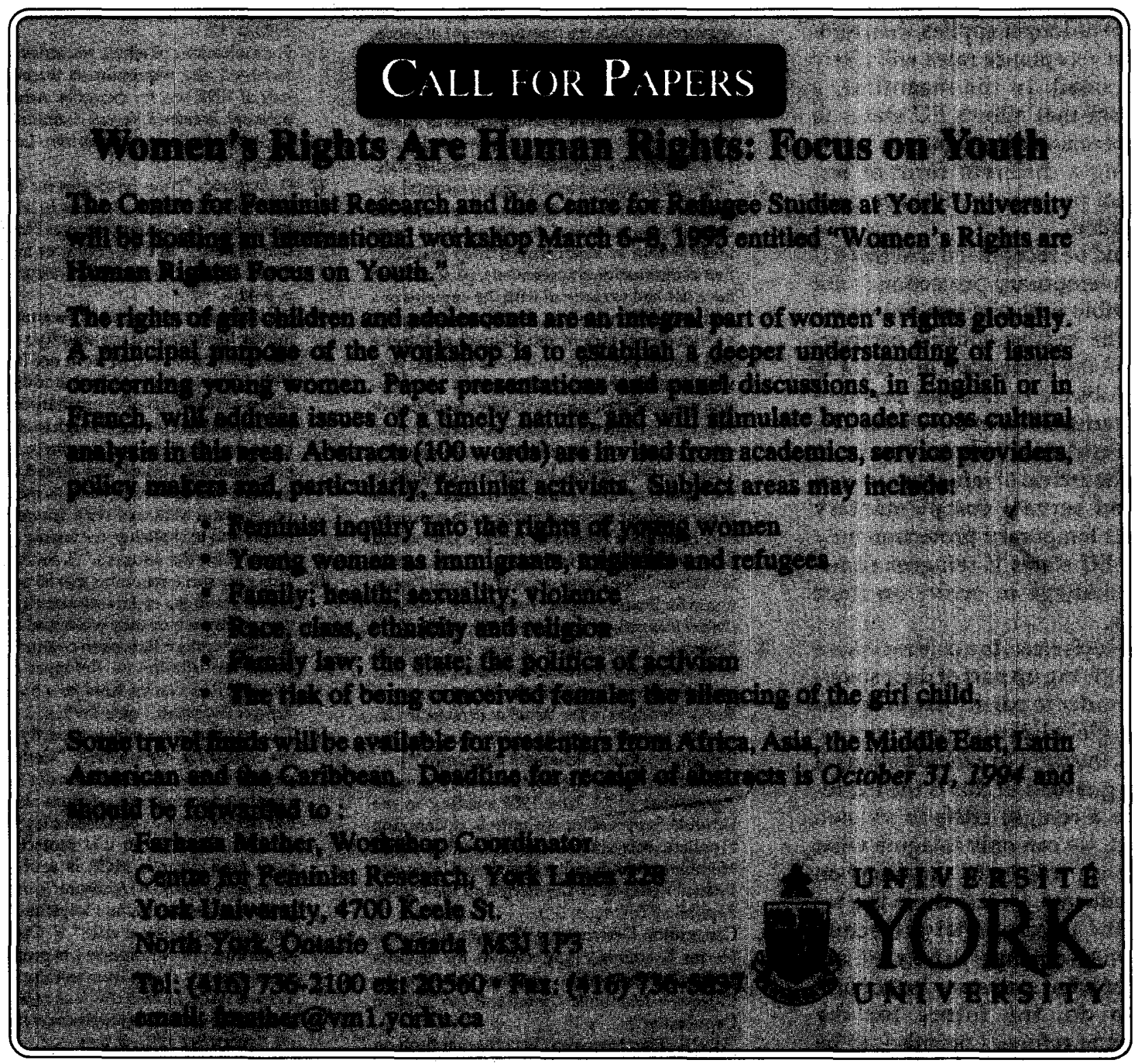

(C) Michael Barutciski, 1994. This open-access work is licensed under a Creative Commons Attribution-NonCommercial 4.0 International License, which permits use, reproduction and distribution in any medium for non-commercial purposes, provided the original author(s) are credited and the original publication in Refuge: Canada's Journal on Refugees is cited. 